\title{
EXPLORING APPROACHES TO FRESH WATER STORAGE AND USES FOR IRRIGATION IN SALINIZED SOUTHWEST COASTAL REGION OF BANGLADESH
}

\author{
Hamidul Huq and *Khalid Md. Bahauddin \\ Institute of Development Studies and Sustainability (IDSS), \\ United International University (UIU), Bangladesh, khalid.bahauddin@gmail.com
}

\begin{abstract}
The agricultural system of coastal regions of Bangladesh is heavily dependent on environmental factors such as the timing, intensity and distribution of the monsoon, soil salinity and the availability of freshwater for irrigation. This study explores and documents the farmers' practices of innovative approaches to fresh water storage and uses in the agriculture and irrigation in the coastal regions of Bangladesh. The study was mostly qualitative in nature but some quantitative primary data were collected based on the study objectives. Primary data were collected through in-depth individual interviews, group discussions, focused group discussions and key informant interviews. The data collection for this study was carried out in the Bajua and Laodob union of Dacope upazilla of Khulna district. This study found that the mainstay of the economy of the study areas is agriculture (51.67\% for the Bajua and $50.43 \%$ for the Laodob union) and bulk of the local population is dependent on farming. The study found that in 2009 the shrimp farming is being stopped in the study areas by collective efforts of villagers, local political leaders and different NGOs. These areas are now affected by severe water scarcity problems and due to lack of water sources and the increasing salinity, the people in the study areas cultivate rice (Aman) once a year, but now produce robi crops in the summer season. Farmers depend mainly on rainwater, canals, ponds and rivers. It noted that groundwater for irrigation using deep tube wall is failed in the study areas because groundwater lever has already gone very down. This study explored that the increasing salinity, lack of water sources, with temperatures rising, the recurrent natural extremes are impacting on agriculture intensifying the vicious cycle of hunger and poverty are becoming more frequent especially in the summer season. It is interestingly noted that the farmers in the study areas dig small/ mini ponds beside agriculture land during rainy season for storing freshwater which are used in summer season for irrigating robi crops because in summer season, the salinity increases in soil and water and, canal and river become silted. This study revealed that because of high salinity in groundwater and surface water, the people of the study areas use rainwater collecting it in the rainy season and storing it for use during the dry season. However, within a short period, insects begin to breed and nuisances created in the water which affects the quality of water using for irrigation and drinking. To prevent this from happening, some people keep two or three Kai fish (Climbing Perch) in the container to eat insects and keep the water clean and, free of nuisances. This study also importantly noted that to keep the stored rainwater free from any nuisances, some people of the study areas place a paste made from two or three pieces of raw turmeric wrapped in a clean cloth into the water container. They use this as herbal repellant in the form of turmeric in order to keep stored rainwater free of pollution. Communities developed these practices out of necessity and these practices are not tested scientifically, but people believe in their efficacy.
\end{abstract}

KEYWORD: Water Storage and Uses, Irrigation, Practice, Coastal Bangladesh

\section{INTRODUCTION}

The natural resources of coastal zone of Bangladesh are very different from the terrestrial counterparts as to require different and special forms of management. Coastal areas are important ecologically, as they provide a number of environmental goods and services. They frequently contain critical terrestrial and aquatic habitats, such as the mangrove forests, wetlands and tidal flats. The other special feature of the coastal zone in its multiple vulnerabilities out of periodic cyclone and storm surges, salinity intrusion, erosion, pollution, and overall lack of physical infrastructure. Coastal natural-resource uses reflect primarily subsistence agriculture with an emphasis on food production, e.g., paddy along with some cash crops and coastal fisheries, which provide a major food and income source (Islam et al, 2004). The southwest coastal region of Bangladesh belongs principally to agroecological zone of Ganges Tidal Floodplain. The tidal floodplain has an almost level landscape crossed by innumerable, often interconnecting, tidal rivers and creeks. Differences in elevation between river banks and basin centers usually are about 1 meter. Clay soils occupy almost the whole landscape. The rivers of this region are characterized by active deposition of sediment causing significant reduction in their drainage capacity (Shampa et al, 2012). Under natural conditions, the land is subject to flooding with silty water at high tides. Tidal water is saline throughout the year. The region is part of an inactive delta of large Himalayan Rivers and is protected from tidal surge by the Sundarban mangrove forest. Rainfall, river flow and tidal water are the major sources of surface water in southwest region of Bangladesh.

Water system in southwest region is embedded in Tidal River, Tidal Basins and Beels. A beel is a natural depression. Bangladesh being a deltaic country, land in the plains has been formed by sediments carried down by Ganges, Brahmaputra and Meghna river systems. Depressions are formed by numerous causes like subsidence of top soil 25 
caused by creation of a vacuum below by decomposition of organic substances mixed with silt, subsidence by tectonic movement, or degradable floods deposit sediment close to the river bank. But the land between two rivers remains low lying (Dasgupta $\mathrm{S}$ et al, 2016). Such a low lying land is also known as a beel. A tidal basin is a depressed low lying or beel adjacent to the sediment-laden tidal rivers. In the southwest region of Bangladesh there are several tidal basins which are very useful for sediment management of sediment laden tidal rivers (Khanom T, 2016). The southwest coastal region has been identified as one of the parts of the world most vulnerable to the effects of a rise in sea level caused by climate change. It is estimated that the sea level in the region has been rising by $3-4 \mathrm{~mm}$ per year for last 30 years. However, the impact of climate change has been compounded by the water management policies successive governments with support and funding from international agencies (Afroz, T., \& Alam, S, 2016).

Salinity increase has been one of the major problems for traditional agricultural practices in coastal Bangladesh for several decades (Rahman et al 2011). "We did not have saline soil and water in our tube wells and ponds before 1975. Salinity started to increase after the introduction of shrimp farming and the Farakka Barrage. Another reason is that people use saline water from the river in their shrimp gher (pond) and sometimes add extra salt to increase the water salinity. As the river and tube well water is very salty we cannot drink it, and have to use deep tube well water" (Brammer, 2014).

Once shrimp cultivation starts, the remaining trees and vegetation also disappear fast because of high salinity and inundation. Sometimes, trees remained longer on the dykes and embankments, but they also disappeared over time because of seepage of saline water. Reeds and grasses that are used for fuel or for making mats are gradually lost because of the rise in saline levels in the waterlogged areas. The number of cultivated species of winter vegetables declined from 1975 to 2006 in all the study areas (Hussain, M.G. and Hoq, M.E, 2012). In the winter season the farmers were busy cultivating rice, instead of vegetables. As they were subsistence farmers both women and men were engaged in rice cultivation, leaving little time to crop winter vegetables. One farmer stated: "People usually don't grow winter vegetables due to high levels of salinity in the vegetable growing season". Summer vegetables (kharif vegetables) were grown from March to October. The summer vegetables eggplant (S. melongena L.), white pumpkin (Benincasa hispida Thunb.), water spinach (Ipomaea aquatica Forssk.), lau (Lagenaria siceraria (Molina) Standl.), elephant foot yam (Amorphophallus campanulatus Roxb.), and cucumber (Cucumis sativus L.) were abundant in the study areas in 1975 , but in 2006 they were rare or absent (Islam M.M et al, 2016).

\section{WATER FOR AGRICULTURE}

Increasing salinity, from among other factors low quality irrigation water, reduced the crop yield to the extent that the farmers lost the interest in cultivating agricultural crops. Growth of rice plants decreases with increased salinity in irrigation water. The groundwater in the southwest region of Bangladesh is highly affected by salinity and sodium and continuous use of such irrigation water, causes high sodium soils, breaks down the soil structure and reduces soil aeration and water infiltration (Murshed-e-Jahan et al 2014). Rain water is the only source for irrigation of Aman rice for most farmers. Heavy rain is required to wash out the soil salinity at the beginning of the rainy season. But, in recent years the rainfall pattern has changed. Rainfall has become erratic and there is a decreasing pattern of rain in the early monsoon, which harms agriculture. Amount of rainfall is decreasing particularly in the pre monsoon and monsoon period (Islam, M.S, 2013). The water of the canal, which used to carry fresh to little saline water in the past, cannot be utilized for irrigation purpose anymore because of its salinity. The pond water which could be used for irrigation purpose has also become saline and unsuitable for agriculture. Besides, the ponds and the canal are also leased out to politically powerful people and brought under intensive fish cultivation, denying the rights to use of other purposes. Since the fresh water table is deep and installing a deep tube well is costly, most farmers cannot afford to utilize the ground water for irrigation (Abdullah, A. $\mathrm{N}$ et al 2016).

In the last thirty years (1970s, 1980s and 1990s) salinity intrusion has degraded soil quality to the extent that some farmers cannot grow agricultural crops (Adnan, S, 2013). Due to lack of sufficient surface water in the dry season $75 \%$ of the water used for irrigation is groundwater. The excessive amount of water pumped up from the Bangladeshi aquifer in relation to the amount recharging it increases the entry of salt water into freshwater aquifers (Hossain, M. S et al 2016). New change in land and water use of southwest region started appearing again in late 1980s through innovation, development and practices of 'rice-prawn gher' farming using fresh water (mainly rainwater), which is a new local agricultural system solely innovated by farmers in the southwest coastal region since mid-1980s (Ali, A. M. S, 2012).

For rice-prawn farming the farmers make perimeter-dykes, which is modified rice field having high wide dikes and a canal inside the periphery of the dikes that retains water during the dry season. In addition to rice and prawn, farmers grow vegetables and fruit trees on the gher banks. The life cycle of prawn and carp is from May/June to December/January, boro paddy is from the end of January to end of April and seasonal vegetables are throughout the year. Before release of prawn post larvae (PL) into the gher, farmers repair the gher dikes and trenches almost every year. They use lime (30-40 Kgs per hectare) during gher preparation to reduce soil acidity. Traditionally, only snail meat was used as prawn feed, but nowadays in addition to snail, farmers use a wide range of homemade and commercial supplementary feeds. Usually, no specific supplementary feeds are provided for fish. Fish share the feed supplied for prawn cultivation. In general, the gher farmers do not use any types of organic fertilizer for boro paddy production as the remains of the feed nutrients that the farmers put in the gher during the prawn and carp fish production supplement paddy field fertility. The farmers usually grow vegetables both during winter and summer seasons on the dikes (Barmon et al, 2004).

Rice-prawn gher sector offers diverse livelihood opportunities for the rural poor. A range of associated groups such as prawn farmers, wild postlarvae collectors, fry traders, snail harvesters, feed traders, prawn traders and day laborers including women and children are involved in this sector. The opportunities for day laborers to find work have increased significantly (Ahmed et al, 2008). Livestock and poultry in rice-prawn gher farming areas have increased. Before riceprawn gher farming had started, landlords or rich farmers 26 
had a large number of cows, and buffaloes and hired local boys to take care of the cows but most of the small, landless and marginal landowners had no cows or sometimes a few of them. Now, more or less, the people are rearing more than two to three cows for milk and cow-dung. Instead of unavailable grazing fields, the gher farm owners and even landless farmers collect feed (grass) from the embankments and store by-product of paddy (straw) for cattle feed. The farmers use the stored straw in the rainy season when feed is not available (Ahsan D, Brandt US, 2016).

\section{OBJECTIVES OF THE STUDY}

Farmers' practices of innovative approaches to fresh water storage and uses in irrigation uses are common, but in small scale and scattered. If these innovations are scientifically documented, then this knowledge can be useful in larger scale in the southwest coastal region of Bangladesh. The uses of locally innovated approaches to fresh water storage and irrigation are also relevant to climate change adaptation of coastal agriculture. Scientifically documentation of these practices is expected to make effective contributions in knowledge sharing with relevant stakeholders towards advocacy for science -policy interface. Considering the discussion above he main objective of this study was to explore and document the farmers' practices of innovative approaches to fresh water storage and uses in the agriculture and irrigation in the coastal regions of Bangladesh.

\section{METHODOLOGY}

This study was mostly qualitative in nature but some quantitative primary data were collected to compliment and comprehend for findings based on the study objectives set. Primary data were collected through in-depth individual interviews, group discussions, focused group discussions and

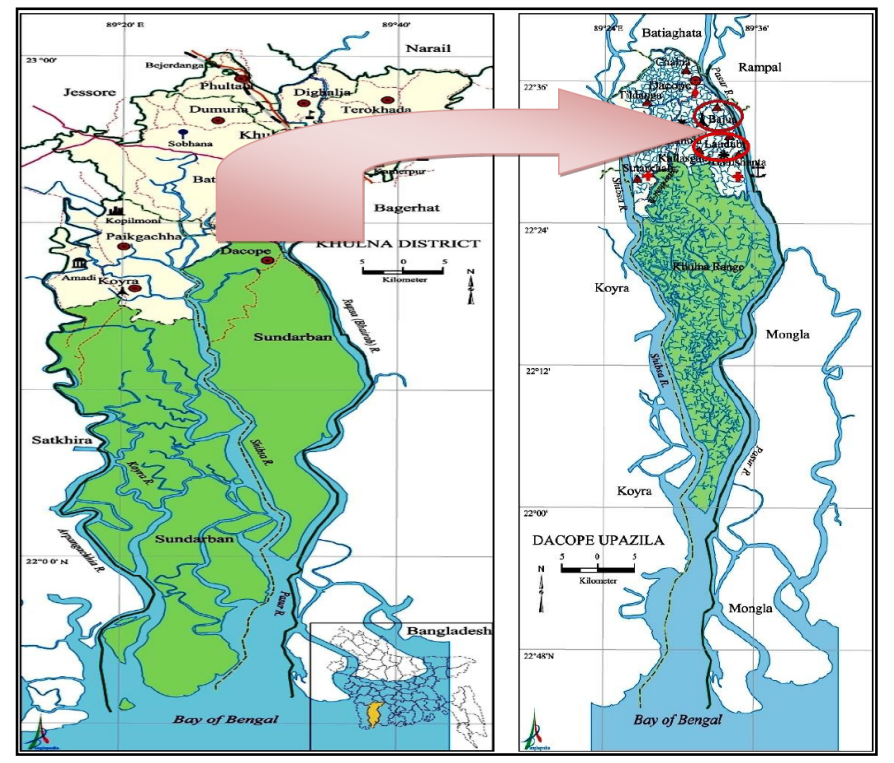

Figure 1. The selected study areas key informant interviews with farmers, women; government and NGO field workers with relevant projects. The data collection for this study was carried out in the Bajua and Laodob union of Dacope upazilla of Khulna district. The study areas were selected purposively based on consultation with relevant stakeholders.

For attaining the research objectives, six in-depth individual interviews, two key informant interviews, four group discussions and six focused group discussions in each this two study unions of Dacope union of Khulna district were conducted using set of checklists and guidelines. Secondary data will be examined critically and organized to get in-depth understanding of irrigation practices and gender dynamics in water management in the study areas.

\section{FINDINGS OF THE STUDY}

\subsection{Major Economic Activities in the Study Areas}

As this study focused on irrigation practices and water management so it reasonably became a matter to be studied in the principal economic activities of the people of study areas such as Bajua and Laodob union of Dacope upazilla of Khulna district.

The mainstay of the economy of the study areas i.e. Bajua and Laodob union is agriculture and bulk of the local population is dependent on farming. According to the livelihood classification of the villagers in the 2011 Census, it's found the evidence that majority of the people in the study areas involved in agricultural activities for their livelihood. The table-1 shows that a great majority of the people $(51.67 \%$ for the Bajua and $50.43 \%$ for the Laodob union) depend on agriculture. The data of this study indicated that people in these areas are predominantly agricultural communities. This was evident when the researchers found that preponderant majority of their fathers and grandfathers were also farmers. Although, agriculture is predominant in both the people of the study areas, there are other occupations represented as well. The second important occupation of the people of the study areas is day labors following by fishing.

Table 1. Major Economic Activities of the People in the Study Areas

\begin{tabular}{|c|c|c|}
\hline Occupation & $\begin{array}{c}\text { Bajua } \\
\text { Union }\end{array}$ & $\begin{array}{c}\text { Laodob } \\
\text { Union }\end{array}$ \\
\hline Agriculture & $51.67 \%$ & $50.43 \%$ \\
\hline Service & $2.39 \%$ & $3.92 \%$ \\
\hline Fishing & $15.32 \%$ & $14.92 \%$ \\
\hline Van driver & $3.83 \%$ & $3.92 \%$ \\
\hline Business & $3.35 \%$ & $7.85 \%$ \\
\hline Day labor & $23.44 \%$ & $18.96 \%$ \\
\hline Total & $100 \%$ & $100 \%$ \\
\hline
\end{tabular}

It is noted that many people who involved in the agricultural activities also do fishing side by side with farming and many fishermen have small land a well for growing some Aman paddy and robi crops. As many as total 41.40 percent people make their living by day labor. This study explored that these people were previously involved in agricultural activities but they had to change the occupation due to economic and environmental factors. This study found that fishing is an important occupation for the people of the study areas. Although research team of this study do not have any specific data on the subsidiary occupation of the people but it quite certain that besides agriculture, they must have some other subsidiary works. It comes true when research team 27 
analyzed the cropping pattern of the people in this area; they harvest only one paddy (Aman) in a year. The saline water and severe lack of freshwater sources do not allow multiple cultivating of different varieties of paddy in their agricultural lands. Cultivation, therefore, is very stack and farmers have nothing to do throughout the seasons of the year. It is therefore, quite logical that they must find out some other supplementary subsistence strategies. Apart from rice cultivation in a year, the people of the study areas also started to grow robi crops in abundance and three robi varieties are watermelon, pumpkin and sweet potato.

\subsection{Entering into Rice Cultivation from Shrimp Farming: Looking at the History of Stopping Shrimp Farming}

Although certain types of economic development activities are beneficial for the macro economy and capital flow to relatively depressed regions such as the Southwest of Bangladesh, shrimp farming adversely affected on the Bajua and Laodob union of Dacope upazilla of Khulna. It was 2007 when people of the Bajua and Laodob union realized that the rapid development of shrimp farming was causing a series of negative environmental and social consequences in their areas. Actually the movement of stopping shrimp farming started in 2007 initiated by local political leaders and some villagers. They convinced people that the shrimp farming of their areas led to reduction in agricultural productivity and the availability of potable water. While it was enhancing the foreign exchange through exports, it created loss of land, food insecurity and social dislocation.

Most of the farmers in the study areas said "before 2007, saltwater intrusion and chemical pollution associated with shrimp aquaculture resulted in irreversible changes in the soil composition of the agricultural lands and surrounding areas and, reduced the productivity of the agricultural and rendered it infertile". In addition, most of the studied people noted that rice production declined significantly in their areas because the encroachment of salt from shrimp pond canals that crossed rice fields. The people in the study areas expressed "the high salinity of the soil in our areas prohibited cultivation of vegetables, destroyed those that serve as cattle fodder thus contributing to mortality of the livestock and reduced availability of dairy and meat". It is observed that in the study areas, before 2007 the degradation of agricultural land was usually followed by a further expansion of the shrimp farming industries. Poor landowners affected by salinity of water and land did not find crops and livestock production to be viable and often had little options but to sell their fields at deflated prices to aquaculture operators or to turn to shrimp aquaculture themselves. In addition, shrimp farming reduced social security and enhanced conflict in the study areas. Politically and financially strong farmers exploited small farmers and marginal farmers. Marginal farmers and small farmers had to sell their farmland at very low prices. Sometimes politically strong farmers captured neighboring farmland without any compensation.

This study revealed that before 2007, high salinity due to extensive shrimp farming affected negatively on the people's health and wellbeing in the study areas. Salinization of freshwater for shrimp farming destroyed the sources of fresh water required for agriculture, livestock, drinking and household and, other purposes. This study importantly noted that the lack of freshwater affected people in the study areas especially women and girls who are responsible for fetching drinking water from long distance, it required two to three hours per day as nearby fresh water sources were affected by salinity, and this long distance of walking everyday affected their physical and mental health. Most importantly this study found that people in the study areas had to drink saline water due to scare sources of freshwater resulting different waterborne diseases. In addition, this study noted that drinking saline water during pregnancy caused hypertension resulting in assorted undesirable maternal and fetal outcomes.

Most of the people of the study areas said "due to extensive shrimp farming before 2007, we saw the gradual disappearance of different grasses, vegetables, fruit and woody trees in our areas. It declined fodder sources and increased mortality rates of livestock. The reduction of animal feed and the pollution and salinization of water supplies due to shrimp farming led to an increase in livestock mortality in shrimp farming areas". This study revealed that rice production in the study areas turned down 68 percent between 1985 and 2005 due to extensive shrimp farming which made the villagers of the study areas food insecured and affected the livelihoods of the people who were dependent on agriculture. On the other hand, the people in the study areas noted "increased salinity due to extensive shrimp farming significantly reduced our production of the agriculture through lack of freshwater and dilapidation the quality of soil". The people of the study areas cited "before 2007, unplanned shrimp farming caused enormous waterlogging in our areas extended from agricultural land to residential areas resulting a great number of people forced to flee their homes and take shelter in the school or government buildings. In addition, this reduced soil fertility for agricultural production, reduced opportunities for freshwater irrigation and created scarcity of fresh drinking water in the villages".

Although substantial economic benefit is the major reason for the increased commercial saline-water shrimp farming, it is the outside leaseholders and local large shrimp farmers that mainly receive economic benefits. While substantial economic benefits were the main rationale for the increase in commercial saltwater shrimp farming, it is the external leaseholders and big local shrimp farmers who mainly gained the economic benefits. The small landowners converted agricultural land into shrimp ponds or lease their lands to the owners of the shrimp farms (large landholders of the village or the outsiders, and often alliances between two parties) since they are trapped by surrounding shrimp ponds. In some cases, socially and politically influential and wealthy shrimp farmers purposefully inundate large areas of agricultural land with saline water when they fail to take lease of agricultural land from small and marginal farmers. Therefore, the poor farmers felt compelled to lease their agricultural lands to the influential and wealthy shrimp farmers as they feared the loss of their rice production due to the increased salinity intrusion in their paddy fields following the inundation of the paddy fields with saline water. Nevertheless, as these farmers no longer had the option to cultivate rice and so they needed to lease their paddy lands to the influential shrimp farmers, the lease conditions are set by those influential people. It is often found that poor farmers did not prefer shrimp farming since they had lack of sufficient land and capital to start commercial shrimp farming, and as they adopt extensive cultivation instead of intensive systems when they used land for shrimp farming, they receive less profit. Consequently, high profits and salinity of land by surrounding shrimp ponds are major reasons for the accelerated shrimp farming, 28 
although the former is mainly related to large landowners and outsiders, whereas the latter is related to small landowners.

Therefore considering all pros and cons, local people with their political leaders and NGOs in the Bajua and Laodob unions raised their voices against the social and environmental problems caused by shrimp aquaculture and took the revolutionary decision together for stopping this farming and, finally they successfully stopped it in 2009 in spite of facing enormous internal and external political pressures and influences.

\subsection{Searching the Challenges of Irrigation and Exploring Farmer's Practices to Fresh Water Storage and Uses for Irrigation under the Adverse Environmental Condition}

It is been more than eight years since the shrimp farming is being stopped in the study areas i.e. Bajua and Laodob union of Dacope upazila, Khulna district. These areas are now affected by severe water scarcity problems in agriculture and secured livelihood due to intense lack of sources of water. Due to lack of water sources, the people in the study areas cultivate rice once a year, but now produce robi crops in the summer season. When people started growing more crops round the year, they faced water scarcity problem. Most crops need more irrigation water for production. Water is therefore a vital factor for high yields. Farmers depend mainly on rainwater, canals, ponds and rivers. It is noted that groundwater for irrigation using deep wall is failed in the study areas because groundwater lever has already gone very down. In the locality of the study areas, back in 15 to 20 years, the people used to store water traditionally; they called it Kua and Indara. They stored groundwater in the Kua, it was a small deep ( $5 \mathrm{ft}-10 \mathrm{ft}$ ) hole which was prepared of mud or brick in the surface area. But people could not able to use it for the long time due to inadequate water from groundwater. To cope with the situation, then the people in the study areas started storing water which locally called Indara prepared of concrete rings and with a depth of $15 \mathrm{ft}-20 \mathrm{ft}$ and after few years of using this, they had to stop it due to further dropped down of the groundwater. Now the main problem of the study areas is the intense lack of water sources.

In the study areas, most of the people are dependent on agriculture. Agricultural practices in the Bajua and Laodob union are dependent on environmental and climatic conditions and, the natural variation. In these areas, Aman paddy is the main rain-fed crop. It is noted that the overall agricultural productivity in the study areas is now very low mostly due to unavailability of irrigation facilities, inadequate rainfall and, siltation of ponds and cannels and, less water flow in the rivers. Based on sources of water and irrigation practices, the people of the study areas cultivate two types of crops in a year which are following:

Table 2. Cultivation Practice based on the Availability of Water and Irrigation Approach

\begin{tabular}{|c|c|c|c|}
\hline Crop & Season & Source of Water & Irrigation Practice \\
\hline Aman & $\begin{array}{c}\text { Rainy season } \\
\text { (Shraban-Bhadra) }\end{array}$ & $\begin{array}{c}\text { Rain, River, Canal, } \\
\text { Pond }\end{array}$ & $\begin{array}{l}\text { The people of the regions cultivate Amon in the rainy season } \\
\text { because of the availability of fresh water. In addition, the } \\
\text { salinity in water and soil in this season is much lower than } \\
\text { rest of the months. The cost of irrigation in this season is } \\
\text { lower compared to summer season which is BDT. 70-80/ day. } \\
\text { The profit of Aman is BDT. } 7000 \text { per bigha. }\end{array}$ \\
\hline $\begin{array}{l}\text { Vegetables and } \\
\text { Watermelon }\end{array}$ & $\begin{array}{l}\text { Summer season } \\
\text { (Magh-Boishkh) }\end{array}$ & Pond and Canal & $\begin{array}{l}\text { The people in the study areas cultivate pumpkin, sweet potato } \\
\text { and mainly watermelon in the summer season. In this period, } \\
\text { the salinity increases due to the lack of rain and siltation of } \\
\text { the river and major canals. In } 2009 \text {, the people of the study } \\
\text { areas explored that these crops grow well in salinity and hot } \\
\text { weather. Interestingly, people prepare small/mini ponds } \\
\text { beside agriculture land during rainy season for storing } \\
\text { freshwater which are used in summer season for irrigating } \\
\text { robi crops. It is noted that the irrigation cost is much higher } \\
\text { than rainy season which is BDT.150-200/day but they said } \\
\text { that good yields compensate this cost and these crops are } \\
\text { more profitable than Aman. The profit of these crops are } \\
\text { higher than Aman which is BDT. } 10,000 \text { per bigha. }\end{array}$ \\
\hline
\end{tabular}

This study found that all the farmers in the study areas depend on rain water for irrigating Aman paddy but sometimes rain does not occurs adequately which hampers the irrigation. In this case, the people of the study areas have to collect water for irrigation from canals and ponds by pumping or/and using labors. All the farmers reported that this process is very expensive and some farmers could not able to afford this. This process is also followed in summer season during robi period which is much more expensive than Aman season. It is reported that if farmers use machine for pumping water from canals and ponds, it costs approximately at BDT. 70 per hour but if they use labors, it costs approximately at BDT. 800 with food for five hours. It found in some places of the study areas that last year both Aman and robi crops were totally damaged due to intense lack of irrigation water.

This study explored that life is not effortless in the villages of Bajua and Laodob union. The levels of food insecurity in the study areas are highly evidenced in the summer season. Most of the people in the study areas are vastly dependent on agriculture but increasing salinity, lack of water sources, with temperatures rising, the recurrent natural extremes are extremely impacting on agriculture intensifying the vicious cycle of hunger and poverty are becoming more frequent especially in the summer season. In the study areas, there is only one annual rice harvest i.e. Aman, that resultants seasonal variation in food availability and prices. The increasing salinity, seasonal droughts and intense lack of 29 
water sources are frequent occurrences which were greatly affected the people of Bajua and Laodob union. These events are highly observed in summer season and they could not able to cultivate any crops other than Aman in rainy season so that they had to rely on only Aman in the whole year which made their life and livelihood insecured.

In 1990, some people in Kocha village of Bajua union tried to cultivate watermelon in summer season when there was high salinity in soil and water and lack of water for irrigation existed. And they were succeed and found that watermelon is good fit with saline environment and needs low amount of water. Then they cultivated pumpkin and sweet potato which were at the same time successful in the summer season with increased salinity. This practice emerged as an epitome of success and now more than 90 percent people of the study areas follow this practice in the summer season and securing their life and livelihood. This is not only acts as a source of income during lean periods, but also provides food security for the farmer's family. It is noted that irrigation for watermelon is done carrying water in pitchers or buckets. In the initial months of cropping, surface water such as ponds and canals available in the water channels created by receding rivers are used. This innovative practice in the saline environment is a clear example of how simple technology can build communities' resilience to the natural extremes bring. This study recommends that as this innovative practice requires low economic costs so replication of this practice is highly desirable in the areas where the increasing salinity in soil and water and scarcity of water are existing.

This study also revealed that the farmers collect irrigation water from canals and nearest ponds through pipes. It is interestingly noted that the farmers in the study areas dig small/ mini ponds beside agriculture land during rainy season for storing freshwater which are used in summer season for irrigating robi crops because in summer season, the salinity increases in soil and water and, canals and river become silted when robi crops planted. Farmers are also using the miniponds for fish cultivation and planting vegetables besides this mini-pond for domestic needs as well as for selling. This innovative practice was started in 2009 in Bajua union. Now this is the main source of water for irrigation and this practice is now following by all adjacent villages.

This study also observed that the poor farmers having economic hardship in the study areas do not have the opportunity to bring water from canals, river by using labors or and, machine, they collect water from ponds or canals by pitcher but most of the cases, it is far from their paddy land causing huge difficulties for the farmers. It is noted that there is no boring system found in the study areas for collecting irrigation water thus farmers of the study areas have to only depend on rain water, canal and pond for irrigation. This study explored that after sowing Aman paddy in the middle periods needs irrigation but there is very few scope for irrigation and in this case, farmers use dew which is fallen at night to their grains. Dew beats up by using stick causes dew falls to the soil and again using long stick spreading this dew to their paddy grains that helps to meet up some sorts of irrigation demand.

This study noted that in dry season, the farmers in the study areas usually use water from narrow canals which spreading beside on the land but it is outrageously noted that many influential people in the villages encroach all canals and they cultivate fishes in the canals which is hampering the irrigation of the most of the farmers in the study areas. These influential people established bamboo net over the canals and catch fish to meet their family demands and commercial purposes. This study found that there are few water related conflicts already happened due to this discrimination. In the localities of the study areas, rainwater is captured in ponds during the monsoonal months and stored for the rest of the year. Typically, the people elevate pond banks to prevent outside water intrusion, and install fences to keep animals away. The surroundings are kept free of trees that readily shed leaves. If ponds become contaminated by outside water, the water is bailed out, lime is applied to the dry pond bed and the water is subsequently cleansed by applying alum. Generally, ponds are dried once in two to three year intervals in order to reexcavate and repair their banks. The people of Bajua and Laodob Union have been practicing this measure to secure water for drinking and irrigation purposes. This practice significantly reduces water scarcity when salinity increases in the study areas where pond excavation is feasible. It noted that the people in the study areas use rainwater for irrigation and drinking purposes. During the monsoonal months, they construct a structure made of bamboo poles and plastic sheets to catch rainwater.

To do this, they secure together four bamboo poles, forming a rectangular shape, with one side about a foot higher than the other. A rectangular plastic sheet is then tied to the four corners of the poles. When it rains, containers are placed to collect water caught by the plastic sheet. This practice has the potential to enhance the availability of potable and irrigation water. In addition, in the study areas, the rainwater harvesting system consists of an arrangement of gutters and pipes to collect water from rooftops and direct it into a storage tank appropriate roofing materials include cement, corrugated iron, thatched straw, etc. Gutters, too, are made from different materials, including corrugated iron sheets, palm wood, betel nut wood, bamboo, and banana plant leaves. A 'first flush' device prevents dirt and leaves from entering the tank 36 during initial rainfall runoff. A tightly fitted lid on the storage tank creates a moisture seal reducing evaporation.

This study revealed that because of high salinity in groundwater and surface water, the people of the study areas use rainwater collecting it in the rainy season and storing it for use during the dry season. However, within a short period, insects begin to breed and nuisances created in the water which affects the quality of water using for irrigation and drinking. To prevent this from happening, some people keep two or three Kai fish (Climbing Perch) in the container to eat insects and keep the water clean and, free of nuisances. This practice, learned from elders, is practiced in the villages of Bajua and Laodob union. This study also importantly noted that to keep the stored rainwater free from any nuisances using for irrigation, some people of the study areas place a paste made from two or three pieces of raw turmeric wrapped in a clean cloth into the water container. They use this as herbal repellant in the form of turmeric in order to keep stored rainwater free of pollution.

\section{CONCLUSION}

This study explored and documented practices to fresh water storage and uses for irrigation used to adapt with adverse environmental and climatic conditions as well as methods employed to avoid loss of livelihood options and assets, and ensure availability of water, the continuation of livelihood activities and ensure agricultural productivity. In this study, researchers attempted to uncover some principles and logic underlying previously unexplored and seemingly arbitrary 30 
beliefs that have been adapted into practices for irrigation by the people of the study areas. When dealing with isolated instances collected from the field, it could appear that these practices have no coherent interrelationship that could justify a community's investment into their utilization.

Communities developed these practices out of necessity primarily, to meet the demands of daily existence and they were developed through trial and error. These practices are not tested scientifically, but people believe in their efficacy. They continue to experiment, innovate and adapt until they find their practices that produce desired results, reinforcing confidence levels. Practices are integrated into local traditions and passed down from generation to generation. Throughout the study process a wide range of data relevant to mechanisms for coping with salinity and lack of water sources were collected. The practices documented, often interwoven with cultural values, are designed or adapted to achieve specific objectives or serve precise purposes. Identical reproduction of these practices in another community or cultural setting may not be possible. However, the principles behind these practices may be replicable.

\section{REFERENCE}

1. Abdullah, A. N., Myers, B., Stacey, N., Zander, K. K.,\&Garnett, S.T. (2016). The impact of the expansion of shrimpaquaculture onlivelihoods in coastal Bangladesh. Environment, Developmentand Sustainability. Advance online publication. doi:10.1007/s10668-016-9824-5

2. Adnan, S. (2013). Land grabs and primitive accumulation indeltaic Bangladesh: Interactions between neoliberal globalization,state interventions, power relations and peasant resistance.Journal of Peasant Studies, 40(1), 87-128.

3. Afroz, T., \& Alam, S. (2013). Sustainable shrimp farming in Bangladesh: a quest for an integrated coastal zone Management. Ocean. Coast. Manag, 71, 275-283. http://dx.doi.org/10.1016/j.ocecoaman.2012.10.006.

4. Ahsan D, Brandt US (2015) Climate change and coastal aquaculturefarmers' risk perceptions: experiences from Bangladesh andDenmark. J of Env Plan Mgt 58(9): 1649-1665. doi:10.1080/09640568.2014.942414

5. Ali, A. M. S. (2012). Rice to shrimp: Land use/land cover changesand soil degradation in Southwestern Bangladesh. Land UsePolicy, 23(4), 421-435. doi:10.1016/j.landusepol.2005.02.001

6. Ahmed, N., Demaine, H., and Muir, J. F (2008), Freshwater prawn farming in Bangladesh: history, present status and future prospects. Aquaculture Research, 2008, 39, $806^{\wedge} 819$ doi: 10.1111/j.13652109.2008.01931.x. Available at: http://onlinelibrary.wiley.com/doi/10.1111/j.13652109.2008.01931.x/pdf

7. Brammer, H. (2014). Bangladesh's dynamic coastal regions and sea-level rise. Climate Risk Management, 1, 51-62. http://dx.doi.org/10.1016/j.crm.2013.10.001
8. Barmon, B. K., KONDO, T., and OSANAMI, F. (2004), Impact of Rice-Prawn Gher Farming on Agricultural and Household Income in Bangaldesh: A Case Study of Khulna District. Journal of Bangladesh Studies, Volume 6.1 (2004). Available at: http://www.bdiusa.org/Journal of Bangladesh Studies/Volume6.1.

9. Dasgupta, S., M. M. Hossain, M. Huq, D. Wheeler (2016). "Facing the Hungry Tide: Climate Change, Livelihood Threats, and Household Responses in Coastal Bangladesh." Climate Change Economics 7, $1-25$.

10. Islam, M.M., Shamsuzzaman, M.M., Mozumder, M.M.H., Xiangmin, X., Ming, Y. and Jewel, M.A. S. (2016). Exploitation and conservation of coastal and marine fisheries in Bangladesh: Do the fishery laws matter? Marine Policy, 76, 143-151.

11. Islam, M.S. (2013). Perspectives of the coastal and marine fisheries of the Bay of Bengal, Bangladesh. Ocean Coastal Manage., 46, 763-796.

12. Islam, M.R. and Ahmad, M (2004), Living in the Coast: Problems, Opportunities and Challenges. PDO-ICZMP, WARPO, Ministry of Water Resources, Government of Bangladesh. Available http://www.warpo.gov.bd/rep/liv/living2.pdf

13. Hossain, M. S., Dearing, J. A., Rahman, M., \& Salehin, M.(2016). Recent changes in ecosystem services and humanwell-being in the Bangladesh coastal zone. Regional Environmental Change, 16(2), 429-443.

14. Hussain, M.G. and Hoq, M.E. (2012). Sustainable Management of Fisheries Resources of the Bay of Bengal-Compilation of national and regional workshop (Report No. SBOBLMEP Pub. /Rep. 2). Support to Sustainable Management of the BOBLME Project, Bangladesh Fisheries Research Institute. Dhaka press, 122 pp.

15. Khanom, T. (2016). "Effect of Salinity on Food Security in the Context of Interior Coast of Bangladesh." Ocean and Coastal Management 130, 205-212.

16. Murshed-e-Jahan, K., Belton. B., Viswanathan, K.K. (2014). Communication strategies for managing coastal fisheries conflicts in Bangladesh. Ocean Coastal Manage., 92, 65-73.

17. Rahman, M. H., Lund, T. and Bryceson, I (2011), Salinity impacts on agro-biodiversity in three coastal, rural villages of Bangladesh. Ocean \& Coastal Management, Volume 54, Issue 6, June 2011, Pages 455-468. Available at: http://www.sciencedirect.com/science/article/pii/S09645691110 $\underline{00317}$

18. Shampa, and Pramanik, M.I.M (2012), Tidal River Management (TRM) for Selected Coastal Area of Bangladesh to Mitigate Drainage Congestion, in International Journal of Scientific Research, Vol.1, Issue 5, June 2012, ISSN 2277-86161 IJSTR@2012. Source: www.ijstr.org 